\title{
Perceptions of High School Students About University
}

\author{
Fahriye Hayırsever \\ Correspondence: Fahriye Hayırsever, Düzce University, Faculty of Education, Turkey. \\ Received: July 17, 2019 \\ Accepted: August 18, 2019 \\ Online Published: August 22, 2019 \\ doi:10.11114/jets.v7i9.4383 \\ URL: https://doi.org/10.11114/jets.v7i9.4383
}

\begin{abstract}
This study aims to determine the perceptions of the high school students about the university and the underlying reasons for these perceptions. The model of this study is descriptive, and it is designed based on qualitative research methodology. The sample of the study consists of 70 students from different high schools located in the city center of Duzce, in Turkey. Maximum variation sampling method, one of the purposive sampling methods, was used to determine the sample of the study. The sample consists of 11th grade students from the selected high schools. The data of the research was collected by interview method. The data of the research was analyzed by content analysis method. According to results of this study, students' perceptions about the university were categorized under two main themes. These themes are "Future and Career" and "Freedom and Autonomy". Within the first main theme, "Future and Career", the sub-theme with the highest frequency is "future". This sub-theme is also important in terms of having the highest frequency among all other sub-themes. Students perceive the university as a turning point in their future lives and think that their future lives will be changed and shaped only by the university. Within the second main theme, two sub-themes with the highest frequency are "being free" and "having an independent life". According to the students, it is also important to be free, socially and personally empowered, and to have the ability to live their own lives during and after university education.
\end{abstract}

Keywords: higher education, university, student's perceptions about university

\section{Introduction}

Over the past forty years, universities have faced major challenges, and undergone major transformations, in their nature and scope, their governance structures, the nature and value of knowledge, and their relationship with the economy and society (Robertson, 2010). However, university has taken a main responsibility since its foundation- to educate individuals. While carrying that responsibility, it carries importance how that term is understood. To Billington (2002), education has two different Latin roots "educare" which means to train or to mould, and "educere" meaning to lead out. With "educare" as an emphasis, education comes to mean the preservation and passing down of knowledge and the shaping of youths according to a pattern set by families, employers, and civic models of acceptable conduct. The other understanding, "educere" sees education as preparing a new generation for the changes that are to get ready them to create solutions to unknown problems, "Educare" calls for education as "mere" training in discrete repeatable skills, and behaviour, giving more importance to such activities as rote memorization and reliable workers for work that requires more rule-bound behaviour and less creativity and critical thought. "Educere" requires questioning, thinking, and creating. And this applies to both the student as creative thinker at work but also to the arts of self-development and responsible citizenship. To Billington (2002), when "educare" predominates, curriculum will be determined by the economic or social needs of society or the state. When "educere" is prominent, the primary purpose of education is not only to train experts in certain fields, but to provide personal autonomy, including creativity, ethical and critical judgment (p.382-384). But as Kuçuradi (1988) emphasized that it is not enough to equip the individual with the knowledge of a profession (TEDMEM, 2018). As Randall \& Good (2004) proposed and in now widely accepted, there should be a balance between educare and educere in the educational systems.

In a parallel with that widely accepted propose, Barnett (1992) explained that universities have two conceptions of mission: dominant and marginal. Dominant conceptions focus on training graduates ready to work; on the other hand, marginal conceptions focus on improving individuals' autonomy and integrity, intellectuals and critical thinking skills. The dominant conception is to provide work-ready graduates, to train applied researchers, to deliver efficient teaching for that purpose, and to extend socially acceptable, pre-arranged opportunities for the individual; those under the marginal conception are to promote life-long learning, to develop an individual's autonomy and integrity, to assist the formation of 
intellectual abilities and perspectives, and to develop critical reasoning. Kalayci, Watty \& Hayirsever (2008) have emphasized faculty members in today universities are expected to adopt the aims under the marginal conceptions, but they prioritize the aims under the dominant conceptions. In another study conducted by Akcatepe (2013), she indicated the faculties adopt the aims under both marginal and dominant conceptions.

There is no doubt that the faculties' views on missions of universities have vital importance. Furthermore, when the aims of state, business and academic community with enormous effects on university, are reached, the demanded quality in the universities can be grasped (Kalayci, Watty, \& Hayirsever, 2008). But it should not be ignored that one of the important stakeholders of university is students themselves, so their vision, perceptions, thoughts have vital importance in reaching the aims, at last quality of the university. It is certain that the changing nature of the student population is impacting on universities and It is a duty of universities to dismiss the gap emerging between student changing expectations and student experience (Lai, 2011; Andrews \& Tynan, 2011, 118).

When the university is thought as a system, students are both the input and output of the system. As an input, students are one of the factors that cause many changes in the social and economic context and affect the university directly. Moreover, they are closely affected by the practices in the university and as the output of this system. It is one of the criteria considered by the public, in determining the quality of the universities. As the output of the university system, students will constitute the most valuable resource of their society, the educated individual (Gunay, 2007). There is also a "feedback" in the system, where students and the university have mutual, reciprocal influence on each other.

For all the aforementioned reasons, it is important to determine the general thoughts and perceptions of the students, their expectations, including their perception of the qualifications that the universities want them to gain, the reasons underlying the students' thoughts about the university, and success meeting these expectations and wishes. It is significant to determine the views of high school students who are in the process of transition to higher education, which is the last step of the formal education system and who make an intensive effort to become a university student. To make sense of their views on the priorities of the university, high schools and university entrance system in Turkey.

There are four kinds of high schools in Turkey, namely general high schools, vocational-technical, religious education and open education high schools. Under these four main groups, there are some more high school sub-types. For example, general high schools include science high schools, social sciences high schools and Anatolian high schools. The number of students attending one of these high schools is nearly 5.7 million (Ministry of Education, 2019). A great vast of these students desire to enter university upon graduating from high school.

In Turkey, there are 206 universities including 129 states and 77 foundations (The Higher Education Council, 2019). Considering that at least one state university exists in each province of Turkey, it can be thought that it will be easier for students to settle in a higher education institution. In 2018, nearly 2.4 million students made selection to enter university after they got enough point in the centrally administered University Entrance Examination; however, only about 857 thousand of them were placed in a degree program (including 2-4-year degree program excluding the nonformal/distance higher education sector) (The Higher Education Council, 2018).

Although more than 1.5 million students could not enter the university, based on the results of that examination, 979 higher education programs were closed especially because they were not preferred by students. The majority of the closed programs are the ones at the faculties of science and literature and the faculties of economic and administrative sciences. The main reason for this situation is that students do not prefer these programs due to future concerns (Komus, 2019) and the "growing anxiety around the world about youth unemployment, even among college graduates” (Barber, Donnelly \& Rizve, 2013, 1).

The future concerns and the fear of the young are not limited to Turkish context. Around the developed and developing countries, there is growing concern about the employment prospects of recent university graduates. In many countries, the problem is more severe: a larger and growing proportion of university graduates are languishing in unemployment, including in both developed and developing countries (Grifth, 2017).

Student pressure on universities to help them get good jobs is not new, but it is also becoming a greater priority of government (Grifth, 2017). Besides the pressure of students, governments and other stakeholders force universities to focus on only technical and discipline based studies, but as an influential report sponsored by the World Bank and UNESCO, Higher Education in Developing Countries: Peril and Promise advocates, general education is an alternative to the existing, largely specialized undergraduate curriculum common in higher education worldwide (Task Force on Higher Education and Society, 2000). At the "macro" level, Universities should respond to the need for change observed in social, economic, administrative and educational fields, and at the "micro" level, should respond to produce immediate solutions to the deepening problems related to content and learning-teaching processes (Kalayci \& Ilhan, 2017).

Higher education is one of the most pressing and controversial educational issues all around the world and there is still an increasing demand for higher education; on the other hand, there are numerous programmes that have been closed and are 
expected to be closed in a few years- especially in Turkish context, which makes it more important to explain the views of high school students related to university. Based on that idea, there are so many studies to find out the views of high school students related to university both in national and international context. There are some studies focusing on high school students' views in both national (Korukoglu, 2003; Sahin \& Yildiz, 2005; Sahin, Zoraloglu, \& Sahin-Firat, 2011; Korkmaz \& Bagceci, 2013; Ertem \& Ari, 2016) and international context (Immerwahr, 2002; Crisp, Palmer, Turnbull, Netelbeck, Ward, \& Schneider, 2009; Xu, 2011; Kandiko \& Mawer, 2013).

The results of the aforementioned studies do not affirm the widely stated idea that students perceive university in monolithic ways (Batchelor, 2006; Briggs, 2006). Because an extended literature review shows that, the perceptions of students about university can be grouped in two headings: (i) university is a place that prepares students for their profession and (ii) university is an opportunity for autonomy. For the first perceptions, Ertem \& Ari (2016); Sahin \& Yildiz (2005); Korukoglu (2003); Sahin, Zoraloglu \& Sahin-Firat (2011) states that high school students perceive the university as a place that prepares them for work and professional life. Similarly, in the studies conducted with university students, students think that the primary purpose of university is to prepare them for the profession (Immerwahr, 2002; Xu, 2011). Secondly, students believe university life/graduation enable them to become more independent and to improve their identity. For example, Sahin, Zoraloglu, \& Sahin-Firat (2011) conclude that high school students think university helps their self-improvement and intellectual development. In his comparative study, Xu (2011) concludes that university students think one of the leading purposes of university is to enable students to be successful in life. Crisp, Palmer, Turnbull, Nettelbeck, Ward \& Schneider (2009); Korkmaz \& Bagceci (2013); Demirtas \& Coban (2014) and Sahin \& Yildiz (2005) made similar conclusions in their studies. After examining the related literature, it is concluded that students think university like an opportunity for being well off financially and for acquiring a meaningful philosophy of life (Bok, 2006, 26).

It should also be emphasised that while students have positive perceptions of higher education, but this depends on their clear expectations about what institutions should provide to support and enable their learning and enhance their career prospects (Kandiko \& Mawer, 2013). It should be noted that there are two types of students at the higher education level. While the first type of students focuses primarily on personal development, learning process and intellectual competence in university preferences; the second type focuses on topics such as grade, status, competition, and more attention to external values $(\mathrm{Xu}, 2011)$. There is no doubt the first group is able to be successful in both academic and professional life. These tendencies influence the variation in perceptions of the students noted in this study.

In short, education planners, those responsible for managing higher education and faculty need to know their future students, their perceptions about university, the differences in their perceptions, and the reasons for these differences, for the following reasons:

- To provide better understanding of student perceptions of university

- To give important clues about quality and standards

- To show a tangible influence on student engagement and retention (Longden, 2006),

- To enable more developed understanding of how perceptions vary across student groups,

- To provide the opportunity to examine the aims / practices of universities in line with students' perspectives / expectations of the university,

- To enable universities to provide better alignment between student expectations and the reality of university experience (Crisp et al, 2009).

For these reasons, in the study, it is aimed to determine the perceptions of high school students on university and the reasons for these perceptions.

\subsection{Purpose}

This study aims to determine the perceptions of the high school students about the university and the underlying reasons for these perceptions.

\section{Method}

\subsection{Research Model}

The model of this research is descriptive. Descriptive studies attempt to describe a situation, problem, phenomenon, service or programme systematically (Kumar, 1996). The study is designed according to qualitative research methodology. Qualitative study is defined as a research method that aims to describe the variation and diversity in a phenomenon, situation or attitude with a very flexible approach so as to identify as much variation and diversity as possible (Kumar, 1996). An important feature of qualitative studies is that qualitative data provide enriched and holistic content to identify complex phenomena, events or situations (Miles \& Huberman, 1994). 


\subsection{Participants}

The sample of the study consists of 70 students from different high schools located in the city center of Düzce in Turkey. In terms of geopolitical placement Duzce, Turkey is among the largest cities between Istanbul and Ankara, and therefore is an important transit point feature. Duzce also has unique socio-economic and cultural structures. Maximum variation sampling method, one of the purposive sampling methods, was used to determine the sample of the study. The aim of the maximum variation sampling method is to identify key dimensions of variations and then finding cases that vary from each other as much as possible. This sampling yields; (1) high-quality, detailed descriptions of each case, which are useful for documenting uniqueness, and (2) important shared patterns that cut across cases and derive their significance from having emerged out of heterogeneity (Benoot, Hannes, \& Bilsen, 2016).

The aim of the selection of different high schools in the research is not to compare the data, but to provide variation in the data according to the types of high schools. In the 2015-2016 academic year, in which the research was carried out, there were five different high school types (total number of high schools in the center of the city is 18). Eight high schools were selected including at least one high school of each type (up to two or three high schools according to the student size of high schools). The sample consists of 11th grade students from the selected schools. The study was carried out with 11th grade students because 12th grade students were busy preparing for the university entrance exam, and 9th and 10th grade students might not have enough knowledge or opinions about the university education yet. The number of students was determined by proportioning to the number of students in high schools. Accordingly, 6 students from a Science High School; 24 students from three Anatolian High Schools; 24 students from two Vocational and Technical Anatolian High Schools; 10 students from an Imam Hatip High School (Religious High School); 6 students from a Fine Arts High Schools were identified. A total of 70 students were selected from all these schools.

Fifty-seven and one-tenths of the sample were female and $42.9 \%$ were male. The average academic success of the students was very good (14.3\%), good (31.4\%), moderate (48.6\%), and pass (4.3\%). It was determined that $1.4 \%$ of the students were in the failed grade point. Students' academic achievement levels generally show a wide distribution.

\subsection{Data Collection Tools and Data Collection}

The data was collected by interview method. Interview provides a unique opportunity to uncover rich and complex information from an individual (Cavana, Delahaye, \& Sekaran, 2001, 138). The interview provides an in-depth knowledge of individuals' experiences, thoughts, feelings and knowledge on a subject (Patton, 2002).

In the study, a semi-structured interview form consisting of two open-ended questions was used. The interviews were conducted in the spring semester of the 2015-2016 academic year. Prior to data collection official permission was received from the managers of each high school, and they were informed about the purpose of the study. Candidate students to be interviewed were determined and the volunteers were selected randomly according to the size of sample. Interviews were conducted during school time and in the school building in rooms determined by the school administration. Each interview lasted approximately 20-25 minutes and all interviews were completed in about three months. While conducting these interviews, it was taken into consideration that these interviews should not interrupt students' lessons. The students were told that their opinions would not be used for any purposes other than the research and would not be shared with their teachers or school management. Data were recorded with the voice recorder with the permission of the students. The opinions of the students who did not want to allow recording with voice recorder were written down by the researcher.

\subsection{Data Analysis}

The data of the research was analyzed by content analysis method. The steps followed in content analysis are as follows:

1. The students were given a code to return to the recorded data during the interview.

2. The interview data were transferred to Microsoft Office Word.

3. The data was read without any modification or classification.

4. The sentences which have the same or similar meaning with each other were brought together to form the codes. According to Strauss \& Corbin (1990, 3), coding is the analytic process through which "data are fractured, conceptualized, and integrated to form theory".

5. The frequency of the codes used by the students was determined.

6. Codes were classified according to similarities and differences.

7. Similar themes were put together to create sub-theme to represent these codes.

8. In the research, 13 sub-themes emerged. 
9. To make a holistic interpretation of the sub-themes and to reach a general conclusion, the themes were reclassified according to their similarities, and the main themes representing these sub-themes were determined. This process is important in terms of bringing data analysis and interpretations into more qualified form. Two main themes emerged in the research.

\subsection{Validity and Reliability}

The process about the validity and reliability of the research is shown below:

1. To ensure the content validity of the interview form, three experts in the field of curriculum and instruction were consulted.

2. Prior to the interviews, three students with similar characteristics were interviewed. In this pre-interview, the appropriateness and comprehensibility of the questions were tested.

3. To ensure the validity of the data, face-to-face interviews were preferred with all the students and all the interviews were conducted sparing the same amount of time and conditions as much as possible.

4. To ensure the internal validity in the thematic coding process, special attention was given upon whether the codes under the themes constitute a meaningful whole. Similarly, to ensure the external validity, all themes were designed to explain the data obtained in the research in a meaningful way.

5. To ensure the reliability of the data, the codes and themes determined during the analysis phase were re-created by an external researcher and then the determined codes and themes were compared.

6. The experts in the field of curriculum development and evaluation were consulted about whether the sub-themes of the codes created for the validity of the data represent the main themes or not. The results were then compared with the analysis results that the researcher carried out.

7. The process of data collection and analysis is explained in detail to ensure the validity of the research results.

8. All the codes generated during the analysis phase are shown in the findings section.

\section{Findings}

In this section, findings obtained for the purpose of the research are given. A total of 109 codes, 13 sub-themes and two main themes were determined. The main themes and sub-themes are shown in Table 1.

Table 1. Distribution of high school students' perceptions about the university

\begin{tabular}{|c|c|c|}
\hline Themes & Sub-themes & $\mathrm{f}$ \\
\hline \multirow{7}{*}{ Future and Career } & Future & 20 \\
\hline & Preparation for the professional life & 11 \\
\hline & A place to achieve goals & 11 \\
\hline & A comfortable life & 6 \\
\hline & Obligation & 6 \\
\hline & A place for challenge & 4 \\
\hline & Subtotal & 58 \\
\hline \multirow{9}{*}{$\begin{array}{c}\text { Freedom and } \\
\text { Autonomy }\end{array}$} & Being free & 11 \\
\hline & Having an independent life & 9 \\
\hline & A place for diversity & 9 \\
\hline & Dreams & 9 \\
\hline & A place for personal development & 6 \\
\hline & A place to serve my country & 4 \\
\hline & A place to socialize & 3 \\
\hline & Subtotal & 51 \\
\hline & Total & 109 \\
\hline
\end{tabular}

The perceptions of the high school students who participated in the study were categorized under 13 sub-themes. Two themes were created from these sub-themes. These themes are "Future and Career" and "Freedom and Autonomy".

All sub-themes are explained within separate titles, and the codes within these themes are clarified with their reasons

\subsection{Future and Career}

The highest rate under this main theme was within the sub-theme "Future" ( $\mathrm{f}=20$ ). The two other important perceptions of the students about the university are "Preparation for the professional life" and "A place to achieve goals" with the same ratio ( $\mathrm{f}=11$ ). Other sub-themes are less frequently expressed, but "Comfortable life", "Obligation" and "A place for challenge". Each sub-theme is explained below along with the code and their reasons. 


\subsubsection{Future}

High school students perceive the university as the "Future" on the first rank. The perceptions and the reasons that form the basis of their views are presented in the Table 2.

Table 2. Students' perceptions and reasons on the theme "future"

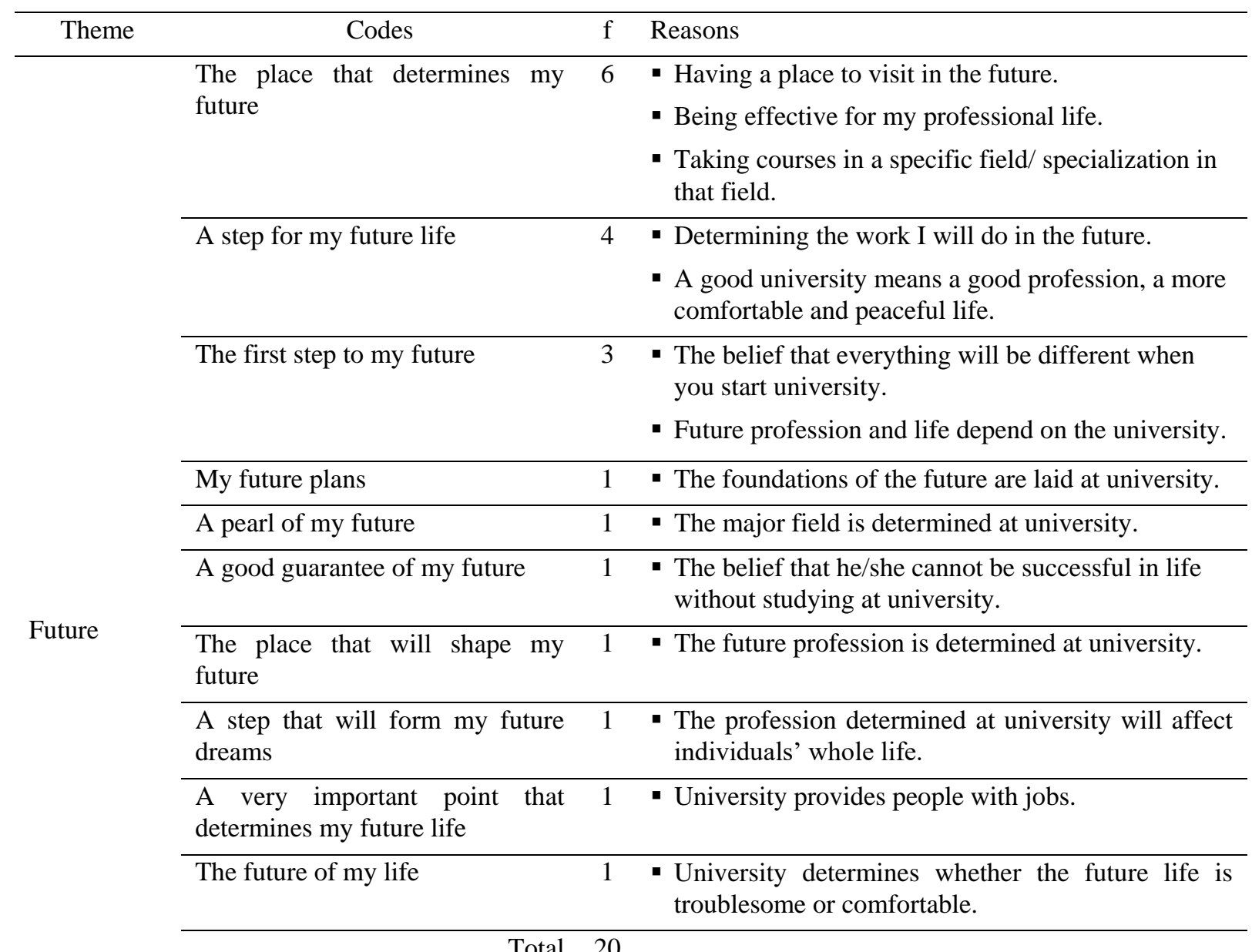

The students' views expressed under the theme "future" are respectively "the place that determines my future, a step for my future life, the first step to my future, my future plans, a pearl of my future, a good guarantee of my future, the place that will shape my future, a step that will form my future dreams, a very important point that determines my future life, the future of my life". The students stated similar views about the importance of the university for their future. When the views are analyzed, it can be seen that the university is perceived as the starting point of their future life. The reason why students think so is that they believe that their real life will start with the university, that everything will be different when they start studying at university and that the education, they will have at university will affect their whole life. The view that "a good university provides a better profession, a more comfortable and peaceful life" is actually a summary of what the university means to the students. The fact that students do not succeed in life without going to university is a remarkable and thought-provoking finding. 


\subsubsection{Preparation for the Professional Life}

Students perceive the university as "Preparation for the Professional Life" (ranked number two). The perceptions and the reasons that form the basis of their views are presented in Table 3.

Table 3. Students' perceptions and reasons for the theme "preparation for the professional life"

\begin{tabular}{|c|c|c|c|}
\hline Theme & Codes & $\mathrm{f}$ & Reasons \\
\hline \multirow{8}{*}{$\begin{array}{l}\text { Preparation for } \\
\text { Professional Life }\end{array}$} & Having a profession & 3 & $\begin{array}{l}\text { - The university that I will study determines } \\
\text { which profession I will have. }\end{array}$ \\
\hline & $\begin{array}{l}\text { The last step to have a } \\
\text { profession }\end{array}$ & 2 & $\begin{array}{l}\text { - Thanks to the university, I can have a better } \\
\text { profession }\end{array}$ \\
\hline & Pre-profession & 1 & $\begin{array}{l}\text { It is necessary to graduate from university to } \\
\text { be able to find a job. }\end{array}$ \\
\hline & $\begin{array}{l}\text { To be more successful in } \\
\text { my profession }\end{array}$ & 1 & $\begin{array}{l}\text { - What I have to do before I have a job is to } \\
\text { study at university. }\end{array}$ \\
\hline & Set up my own business & 1 & \\
\hline & A good profession & 1 & \\
\hline & $\begin{array}{l}\text { A life related to my } \\
\text { profession }\end{array}$ & 1 & \\
\hline & Total & 11 & \\
\hline
\end{tabular}

It is seen in Table 3 that students perceive the university as a preparation for professional life. According to these students, the university means "having a profession, the last step to have a profession, pre-profession, to be more successful in my profession, set up my own business, a good profession, a life related to my profession". Students believe that university education is necessary to have a job, and that the university will help them have better professions. Students regard university education as important only because it is the only way to be able to have a profession /job.

\subsubsection{A Place to Achieve Goals}

Students perceive the university as "A Place to Achieve Goals". The perceptions and the reasons that form the basis of their views are presented in Table 4.

Table 4. Students' perceptions and reasons for the theme "a place to achieve goals"

\begin{tabular}{|c|c|c|}
\hline Theme & Codes & f $\quad$ Reasons \\
\hline \multirow{9}{*}{$\begin{array}{c}\text { A Place to } \\
\text { Achieve Goals }\end{array}$} & The purpose of my life & $\begin{array}{l}2 \text { - Starting/Getting into university, becoming } \\
\text { successful and have a good job. }\end{array}$ \\
\hline & A step to reach the goal & 2 - University is necessary to reach the goals \\
\hline & The last step to start the job & 1 - You can get a job after you graduate university. \\
\hline & The first step to my goal & $\begin{array}{l}1 \text { - It is the first step for the goals such as master } \\
\text { education, foreign language etc. }\end{array}$ \\
\hline & $\begin{array}{l}\text { The place where all my dreams } \\
\text { come true }\end{array}$ & 1 \\
\hline & $\begin{array}{l}\text { The last step that I put forward } \\
\text { for my life }\end{array}$ & 1 \\
\hline & A new life & 1 \\
\hline & A fresh start & 1 \\
\hline & The guarantee of my life & 1 \\
\hline
\end{tabular}

Within the scope of this theme, the students stated that "the purpose of my life, a step to reach the goal, the last step to start the job, the first step to my goal, the place where all my dreams come true, the last step that I put forward for my life, a new life, a fresh start, the guarantee of my life". Two important results were obtained from the students' views. The majority of students described the university as the first and the most important step in achieving their goals. They even stated that the 
only purpose of their lives was to start university. That a student described the university as "the last step he/she puts forward for his/her own life" reflects the idea that he/she has no other option than starting/getting into the university. The second important result is that the real purpose of their lives is becoming successful and has a good job. However, the university is only a tool for this purpose, and there is only one student who thinks that starting/getting into university is necessary for the goals such as master education, foreign language.

\subsubsection{A Comfortable Life}

Students perceive the university as "A Comfortable Life". The perceptions and the reasons that form the basis of their views are presented in Table 5.

Table 5. Students' perceptions and reasons for the theme "a comfortable life"

\begin{tabular}{|c|c|c|c|}
\hline Theme & Codes & $\mathrm{f}$ & Reasons \\
\hline \multirow{4}{*}{ A Comfortable Life } & $\begin{array}{l}\text { The last step for a comfortable } \\
\text { life }\end{array}$ & 1 & $\begin{array}{l}\text { - Get rid of exams, pressure and teachers in high } \\
\text { school } \\
\text { - University is more comfortable than high school }\end{array}$ \\
\hline & Good Life Conditions & 2 & $\begin{array}{l}\text { - A good university means a good life } \\
\text { - A good university means a comfortable life }\end{array}$ \\
\hline & Quality Life & 1 & $\begin{array}{l}\text { - Going to a good university is to save your } \\
\text { future and your life }\end{array}$ \\
\hline & Feel Relieved & 2 & $\begin{array}{l}\text { - University is described as a comfortable place } \\
\text { - The belief that you can overcome the challenges } \\
\text { at university }\end{array}$ \\
\hline
\end{tabular}

According to Table 5, the views expressed under the theme of a comfortable life are "the last step for a comfortable life, good life conditions, quality life, feel relieved". When the reasons why students think like this are analyzed, it can be stated that especially two views come forward. First, students think that university education is more comfortable and less repressive than secondary education. The second view is that a good university means a good and comfortable life. Students believe that their future will be saved through the university education.

\subsubsection{Obligation}

Students perceive the university as an "Obligation". The views and the reasons that form the basis of their perceptions are shown in Table 6.

Table 6. Students' perceptions and reasons for the theme "obligation"

\begin{tabular}{|c|c|c|c|}
\hline Theme & Codes & $\mathrm{f}$ & Reasons \\
\hline \multirow[b]{4}{*}{ Obligation } & I have to study at university & 2 & \multirow{4}{*}{$\begin{array}{l}\text { - It is important for every person to graduate from } \\
\text { university. } \\
\text { - My Parents expect me to get into university. } \\
\text { - It provides job opportunities. } \\
\text { - Everyone takes university entrance exam. }\end{array}$} \\
\hline & It is a must & 2 & \\
\hline & Not to embarrass my family & 1 & \\
\hline & $\begin{array}{l}\text { To be able to say "I studied at } \\
\text { university" }\end{array}$ & 1 & \\
\hline
\end{tabular}

Students, under the theme of obligation, stated "I have to study at university, it is a must, not to embarrass my family, ensure success". They perceive going to university as an obligation as the students and their parents think that university education is a must. This obligation is based on the perception that students and their families perceive that university education is necessary. This obligation stems from the perception that every high school graduate must go to university. This finding shows that, as in the other findings, the students think that both they and their families are anxious about the future. 


\subsubsection{A Place for Challenge}

Students perceive the university as "A Place for challenge". The views and the reasons that form the basis of their perceptions are shown in Table 7.

Table 7. Students' perceptions and reasons for the theme "a place for challenge"

\begin{tabular}{|c|c|c|c|}
\hline Theme & Codes & $\mathrm{f}$ & Reasons \\
\hline \multirow{5}{*}{$\begin{array}{l}\text { A Place for } \\
\text { Challenge }\end{array}$} & Being afraid & 1 & \multirow{5}{*}{$\begin{array}{l}\text { - Staying away from my family. } \\
\text { - } \quad \text { It is a big decision for me. }\end{array}$} \\
\hline & Loneliness & 1 & \\
\hline & Over-estimating & 1 & \\
\hline & $\begin{array}{l}\text { The moment of encountering/ } \\
\text { confronting life }\end{array}$ & 1 & \\
\hline & Total & 4 & \\
\hline
\end{tabular}

The students' views on this theme are "being afraid, loneliness, over-estimating, the moment of encountering/ confronting life". Earlier findings revealed that students felt compelled and relatively more determined to go to university. However, here, it is understood that a small number of students are afraid of going to university. Students feel that fear as going to university is a big decision for them and they think they will be away from their families.

\subsection{Freedom and Autonomy}

The students' views on the theme "Freedom and Autonomy" are under the following subthemes "being free", "having an independent life", "a place for diversity", "dreams", "a place for personal development", "and a place to serve my country", "a place to socialize". Each sub-theme is described below.

\subsubsection{Being Free}

Students perceive the university as "Being Free". The views and the reasons that form the basis of their perceptions are shown in Table 8.

Table 8. Students' perceptions and reasons for the theme "being free"

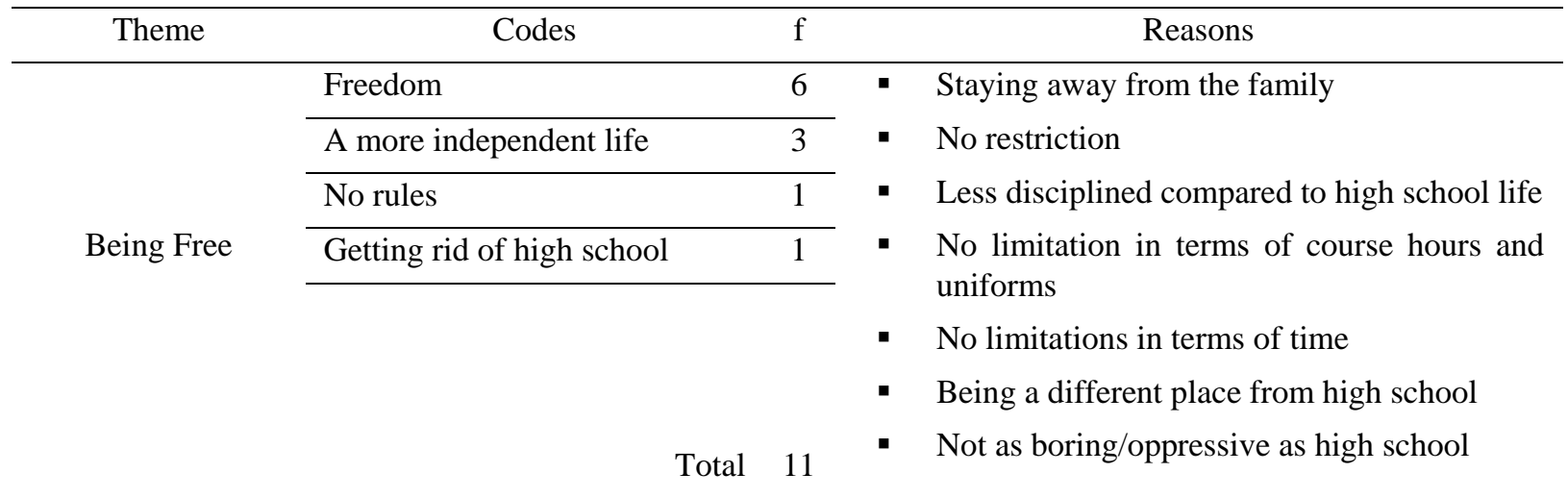

Students perceive the university as being free in the first place under the theme of freedom and autonomy. Within the scope of this theme, the statements are "freedom, a more independent life, no rules, getting rid of high school". The reasons for these perceptions are the fact that the university is a place where restrictions, discipline and rules are less, and living in a place away from the family. They also think that the course periods at university are more flexible. When the opinion of the students that perceive university as getting rid of high school is analyzed, it can be inferred that secondary education is a very hard. 


\subsubsection{Having an Independent Life}

Students perceive the university as "Having an Independent Life". The views and the reasons that form the basis of their perceptions are shown in the Table 9.

Table 9. Students' perceptions and reasons for the theme "having an independent life"

\begin{tabular}{|c|c|c|c|}
\hline Theme & Codes & $\mathrm{f}$ & Reasons \\
\hline \multirow{5}{*}{$\begin{array}{c}\text { Having an } \\
\text { Independent Life }\end{array}$} & Standing on your own feet & 5 & \multirow{5}{*}{$\begin{array}{l}\text { - } \text { Being alone without your family } \\
\text { - Determining my future life criteria } \\
\text { - It is effective to having a profession } \\
\text { - Having a job will make me feel } \\
\text { independent }\end{array}$} \\
\hline & Having a higher status & 1 & \\
\hline & Self-help & 1 & \\
\hline & Earn money independently & 1 & \\
\hline & Saving my life & 1 & \\
\hline
\end{tabular}

A group of students identified the university with an independent life (Table 9). The students' views "standing on your own feet, having a higher status, self-help, earn money independently, saving my life" indicate that they aim to achieve an independent life through university education. When the reasons were analyzed, the students emphasized that both the university and a profession would liberate them and help them gain the ability to lead their own lives rather than only having professional skills through university education. Another important result is that while being away from the family takes a place under the subtheme that there are no rules and restrictions, standing on their own feet was expressed as living alone and maintaining life alone. It can be said that these skills are important skills that increase students' self-confidence.

\subsubsection{A Place for Diversity}

Students perceive the university as "A Place for Diversity". The views and the reasons that form the basis of their perceptions are shown in the Table 10.

Table 10. Students' perceptions and reasons for the theme "a place for diversity"

\begin{tabular}{|c|c|c|c|}
\hline Theme & Codes & $\mathrm{f}$ & Reasons \\
\hline \multirow{6}{*}{$\begin{array}{l}\text { A Place for } \\
\text { Diversity }\end{array}$} & A very different place & 3 & \multirow{6}{*}{$\begin{array}{l}\text { - Having to go to a different city / place for } \\
\text { university. } \\
\text { - Students will come to the university from } \\
\text { different places. }\end{array}$} \\
\hline & New people/friends & 2 & \\
\hline & A new learning process & 1 & \\
\hline & Different lifestyles & 1 & \\
\hline & Different thoughts & 1 & \\
\hline & Another life & 1 & \\
\hline
\end{tabular}

Students also perceive the university as a place that has diversity. The views expressed under this theme are " $a$ very different place, new people/friends, a new learning process, different lifestyles, different thoughts, and another life". The main reason why students think like this is that they will be able to go to a university somewhere else rather than the city where they currently live and that different students will come from different cities. Students will have the opportunity to experience different lifestyles, different thoughts, and new people, and experience a new learning process through getting into university. These views may suggest that students are willing to be open to diversity. 


\subsubsection{Dreams}

Students perceive the university as the birthplace of "Dreams". The views and the reasons that form the basis of these perceptions are shown in the Table 11.

Table 11. Students' perceptions and reasons for the theme "dreams"

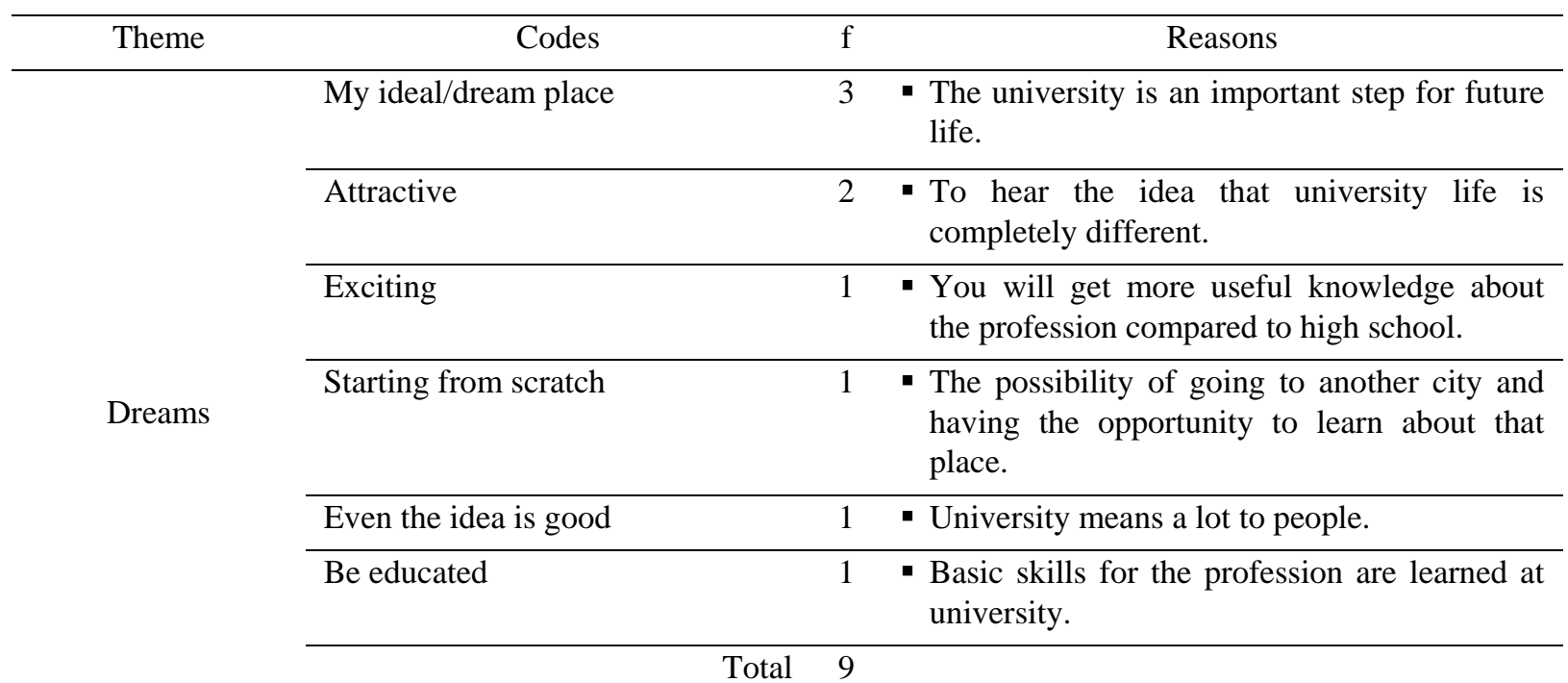

When Table 11 is analyzed, university, to some students, means the biggest dream of their lives. The students perceive the term university as "my ideal/dream place, attractive, exciting, starting from scratch, even the idea is good, be educated". The idea of "starting from scratch" is a remarkable finding. Students put an end to their life before university and dream of a life from scratch. This view shows that the university is of vital importance to them. It is important that the students think of the university as an intriguing and exciting place to get the feeling that university life is a completely different place in order to show how great their expectations are.

\subsubsection{A Place for Personal Development}

Students perceive the term university as "A Place for Personal Development". The views and the reasons that form the basis of their perceptions are shown in Table 12.

Table 12. Students' perceptions and reasons for the theme "a place for personal development"

\begin{tabular}{clll}
\hline Theme & \multicolumn{1}{c}{ Codes } & f & \multicolumn{1}{c}{ Reasons } \\
\hline & Improve my personal development & 1 & - People grow during university years. \\
\cline { 2 - 5 } & Develop a system of thought & 1 & - It is a place where ways of thinking are taught. \\
\cline { 2 - 5 } & Increasing my self-confidence & 1 & - People at university take care of themselves. \\
\cline { 2 - 5 } $\begin{array}{c}\text { A Place for } \\
\text { Personal } \\
\text { Development }\end{array}$ & Allowing personality formation & 1 & \\
\cline { 2 - 5 } & Making my own decisions & 1 & \\
\cline { 2 - 5 } & Acquiring basic knowledge & 1 &
\end{tabular}

The meaning of university to some students participating in the research is to ensure personal development. The views within the scope of this theme are less predominant than other views. The views of students are "improve my personal development, develop a system of thought, increasing my self-confidence, allowing personality formation, making my own decisions, acquiring basic knowledge." These views are quite different from the idea that university is a way of having a profession. University education provides students with the formation of personality, teaches ways of thinking and gives important clues about the roles of the university. 


\subsubsection{A Place to Serve My Country}

Students perceive the term university as "A Place to Serve My Country". The views and the reasons that form the basis of their perceptions are shown in Table 13.

Table 13. Students' perceptions and reasons for the theme "a place to serve my country"

\begin{tabular}{clll}
\hline Theme & \multicolumn{1}{c}{ Codes } & $\mathrm{f}$ & Reasons \\
\hline & To become a role model & 1 & - To graduate from university is a privilege. \\
\cline { 2 - 2 } $\begin{array}{c}\text { To be a beneficial/productive } \\
\text { A Place to Serve } \\
\text { My Country }\end{array}$ & $\begin{array}{l}\text { - People will respect my word more when I am } \\
\text { individual to the country }\end{array}$ & $\begin{array}{l}\text { educated. } \\
\text { To have a voice for the country } \\
\text { in the future }\end{array}$ & $\begin{array}{l}\text { - When I am educated, I will be considered more } \\
\text { important by the society. }\end{array}$
\end{tabular}

Total 4

The students who participated in the research stated that it would be possible for them to be more beneficial/useful individuals for their country. Under this theme, their views are "to become a role model, to be a beneficial/productive individual to the country, to have a voice for the country in the future". Especially important is the idea. "to have a voice for the country in the future." Students believe that university education is especially necessary to achieve this goal. They also emphasized the necessity of university education in order to be an important individual in society.

\subsubsection{A Place to Socialize}

Students perceive the term university as "A Place to Socialize". The views and the reasons that form the basis of their perceptions are shown in Table 14.

Table 14. Students' perceptions and reasons for the theme "a place to socialize"

\begin{tabular}{|c|c|c|c|}
\hline Theme & Codes & $\mathrm{f}$ & Reasons \\
\hline \multirow{3}{*}{ A Place to Socialize } & To make friends & 2 & \multirow{3}{*}{$\begin{array}{l}\text { - It is good to make new friends when I go to } \\
\text { university. } \\
\text { - I will be able to spend more time with my } \\
\text { friends. }\end{array}$} \\
\hline & To be able to wander outdoors & 1 & \\
\hline & Total & & \\
\hline
\end{tabular}

The final perception students expressed about the university, is that it is a place that will enable them to socialize. They attach more importance to this view because "they will make friends and spend more time with them when they get into university."

\section{Result and Discussion}

This study revealed that the most important expectation of high school students is to ensure that they attend to a good university and thus have a good profession. However, student perception of the purpose of higher education to be a place for personal and social development, beyond the confines of employability. This confirms once again the results of other previous studies. The results of this study show that the number of students who want to go to university and see it as the sole purpose of their lives is increasing day by day. This result should be regarded as an important signal for decision makers of both the country administration and the education system because the socio-economic development of a country affects the expectations of the young people of that country in a positive or negative way. This applies to all students of different socioeconomic levels and different types of high school.

This study is limited to just a city in Turkey. However, in later studies, cities with different characteristics can be examined and compared. This comparison can be also made between different countries and Turkey. A meta-analysis can be done by examining all the related studies in the literature. This and similar studies are important to learn about the expectations of students who are the most important stakeholders of the education system. Therefore, it should be kept in mind that all changes in the education system at micro or macro level will affect the students first. In this study, which aims to determine the perceptions of high school students about university, it is aimed to answer what the university means for the students studying at different high schools and why they want to go to the university. Through the collected data, it was determined how the purpose of higher education is considered by students and what it should actually be.

In this study, students' perceptions about the university were categorized under two main themes and 13 sub-themes. The first theme is "Future and Career" and its sub-themes are "Future, preparation for the professional life, a place to achieve goals, a comfortable life, obligation, a place for challenge". The second main theme is "Freedom and Autonomy" and its sub-themes are "being free, having an independent life, a place for diversity, dreams, a place for personal development, a 
place to serve my country, and a place to socialize". When the frequency of the students' views on both main themes is analyzed, it was determined that they had a frequency level which was very close to each other. In this section, three sub-themes with the highest frequencies are described within the scope of each main theme.

Within the first main theme, "Future and Career", the sub-theme with the highest frequency" is "future". This sub-theme is also important in terms of having the highest frequency among all other sub-themes. Students perceive the university as a turning point in their future lives and think that their future lives will be changed and shaped only by the university. Under the main theme of the future and career, two other important sub-themes are "preparation for the professional life" and "a place to achieve the goals". When all these three sub-themes are put together, it emerges the idea that the most important and even the only thing that should be done for the construction of their future is to have a good profession. Students think that if they do not go to university, they will never have a profession.

Ertem \& Ari (2016) states that high school students defined the university as a place that guarantees the profession and the future. In another study conducted by Sahin \& Yildiz (2005), high school students stated that the roles of the university are to prepare them for work and professional life. In the studies conducted with university students, students think that the primary role of the universities is to prepare them for the profession (Korukoglu, 2003; Sahin, Zoraloglu, \& Sahin-Firat, 2011; Xu, 2011). In the study by Immerwahr (2002), most American families believe that university education has taken on the importance of high school education in the past and has become a necessary prerequisite for a good job and a comfortable life. In the study, $84 \%$ of these families stated that having a university certificate/diploma is very important for the students to develop while $77 \%$ stated that going to university today is more important than it was ten years ago. Sahin, Zoraloglu \& Sahin-Firat (2011) found that some of university students in Turkey, especially the ones who were exposed to the difficulty of getting into university, prefer a particular field of study to learn about profession, to be able to have a job and guarantee their lives. He also found that students had to choose the departments that they were less or not interested in studying rather than the departments they really want. These statements may cause students to face the situation of not being able to reach their expectations from higher education which they see as the key to their future.

In the latest PISA report published by OECD, it was stated that the students who failed most of the international exams in some countries were those who wanted to go to university at the highest rate. The report explains the reason of this situation by emphasizing the high prestige and economic return of university education in these countries (Sirin, 2017). In this study, it can be concluded that most of the students believe that they will get rid of the difficulties in their lives by going to university because they feel anxious about their economic situation. Considering that the students participating in the research have different success levels, it can be said that they are in line with the results of the OECD report. Students dream of going to the university, which they consider as the only option, regardless of their level of success or interest. However, according to the university entrance examination results in 2018 (Turkey), the number of students who applied is three times higher than the number of students who could get into university through the result they took from the exam (The Higher Education Council, 2018) Considering this fact, it can be stated that only one-third of the students can realize his/her dreams of getting into university to have a good job and a comfortable life. The rest will not be able to realize this important dream and it will be inevitable for them to get disappointed.

The students in the sample of this study, including vocational high school students, have the same opinion. Considering that the aim of vocational high schools is to provide individuals with occupations in the field they study, it is an important finding that these students also want to continue to study at university. However, when the 2018 entrance exam results are analyzed in terms of high school types, it is seen that the rate of placement of vocational high school students in a higher education program is lower when compared to science high schools and Anatolian high schools. On the other hand, Aksoy (2018) states that the education concept in Turkey is based on only the smartest, most hard-working students or the ones who are at a certain socio-economic level can benefit from academic education and higher education opportunities. He also stated about that it is based on the discourse that it is a good approach for the rest of the students to directly go into business life by taking religious, vocational, technical or non-formal education. Aksoy (2016) stated that the idea of sending those who are considered as academically unsuccessful to vocational high schools is actually a class problem, and he emphasized that the problem results from the economic, social and political conditions and unfair income distribution in the country.

Another main theme found in this study is "Freedom and Autonomy". Within this main theme, two sub-themes with the highest frequency are "being free and having an independent life". According to the students, what is important during and after university education is not only to have a profession, but also to be free and to have the ability to live their own lives. Most students perceive the university as an opportunity to realize themselves. This shows that high school students do not focus on starting a new life through the university, but focus on the idea that the university is helping to improve them. 
In the study, some students perceive the university as a place where they gain their autonomy and acquire competences such as standing on their own feet and becoming independent. In addition, a group of students state that university has no rules; it is not as disciplined a place as high school; class hours are more flexible. These results suggest that while some of the students perceive the university as gaining freedom in a more limited space, others perceive it as more vital and broader context. Dewey (1996) states that schools should open the way to gain personal abilities by developing common areas of interest to individuals in a free environment and ensures the independence of individuals' learning. In the study of Sahin \& Yildiz (2005), high school students expressed other roles of the university as raising free individuals and representing freedom of thought. In the same research, high school students perceive university students as more independent and independent individuals. Moreover, it was stated that especially female students perceive the university as a means of gaining their individual rights.

According to Crisp, Palmer, Turnbull, Nettelbeck, Ward \& Schneider (2009), university students stated that independence and freedom were important values to gain during/after university education. As a result of the study conducted by Korkmaz \& Bagceci (2013), it was found that high school students define the university as "the expression of freedom" with the highest frequency. Similar results were obtained in Demirtas \& Coban's study (2014).

The third important sub-theme of the second main theme in the research is "a place for personal development". Within this sub-theme, students perceive the university as place where they are able to increase self-confidence, make their own decisions, and improve their personality and system of thought. In the study of Sahin, Zoraloglu \& Sahin-Firat (2011), "personal development is among the views of university students about the roles of the university. However, these roles are considered to be of lower priority compared to other roles of the university. In this study, although students perceive university as important for personal development, they do not rank this first in the ranking. In his study, Immerwahr (2002) found that although the primary role of higher education is to train graduates ready for work, families emphasize the importance of personality development and communication skills.

Considering all the results of the research, two basic views emerge. A group of students perceive the university as a place which provides them with a good profession, and as an important turning point which guarantees the construction of their future lives. Another group of students perceive university as a place where they can have freedom, autonomy, independence; where they can achieve their dreams, develop their personalities and socialize with the diversity it has. This result is relevant with many research results. According to both high school and university students, preparation for work and profession takes the first place in terms of the roles of the university; and roles such as developing a free system of thought and personality, representing ideas and freedom of thought are the second and third in the majority of the researches in the related literature. These results show that, as Barnett (1992) points out, the dominant roles of higher education such as educating graduates ready for professional life are given higher priority by students. According to Kalayci, Watty \& Hayirsever (2008), faculty members working in the university faculties of business administration stated that more dominant aims are already in the foreground in higher education system and universities. In the study conducted by Akcatepe (2013), it was stated that both the dominant and higher education objectives should be adopted by the faculty members of education faculties.

These two cases also confirm that Billington's (2002) epistemological analysis of the concept of education, that of the important difference between education as "educare" and that of "educere." The educational approach which is related to a specific skill for a particular profession and which allows students to explore both the world and themselves sometimes conflicts and mostly the former approach (educare) becomes the determinant of the education system. Billington stated that educare is shaped according to the economic or social needs of the society or state. Thus, while students predominantly perceive higher education important for "educare" or professional qualification, it is clear students will also value curriculum and practices based on the educare approach.

It may be predicted that a university missing the educere dimension will face student resistance and dissatisfaction. As it is only focused on gaining knowledge and skills related to the profession, students may be asked to ask what they will do with these knowledge and skills, as Billington points out. Aksit (2002) stated that unlike adults and intellectuals, high school students perceive the university in its popular, social dimension. Aksit (2002) emphasizes that university should be perceived as an institution that educates individuals who process and develop skills rather than a place which is perceived as an institution that brings work, profession, career and image. Similarly, Kucuradi (1988) states that the aim of education should not only be to provide the desired behaviors to the individual or to equip him / her with the knowledge of a profession, but also to give him / her the characteristics of being a human (TEDMEM, 2018).

The research in this study shows that, especially considering the fact that the majority of high school graduates aim to go to university for work and profession, they also value the effect of higher education on a social, personal, intellectual level, and as a support for greater autonomy and freedom. 


\section{References}

Akcatepe, A. G. (2013). The views of academics at the department of educational sciences at faculties of education on the aims of higher education. (Master's thesis, Gazi University, Ankara, Turkey). Retrieved from https://tez.yok.gov.tr

Aksit, B. (2002). Bilgi toplumuna geçiş, sorunsallar, görüşler, yorumlar, eleştiriler, tartışmalar. Ankara: TÜBA

Aksoy, H. H. (2016). Meslek liselerinin günümüzdeki sorunlu işlevi. Eleştirel Pedagoji, 48, 48-50.

Aksoy, H. H. (2018). Türkiye'de meslek liseleri öğrencilerine sunulan eğitime ilişkin eleştirel bir betimleme. Eleştirel Pedagoji, 56, 4-10.

Andrews, T., \& Tynan, B. (2011). Changing student learning preferences: What does this mean for the future of universities? In G. Williams, P. Statham, N. Brown \& B. Cleland (Eds.), Changing Demands, Changing Directions. Proceedings ascilite Hobart 2011. (pp.118-122). Retrieved from:

http://www.ascilite.org/conferences/hobart11/downloads/papers/Andrews-full.pdf

Barber, M., Donnelly, K., \& Rizve, S. (2013). An avalanche is coming: Higher education and the revolution ahead. Institute for Public Policy Research. London, UK. https://doi.org/10.17323/1814-9545-2013-3-152-229

Barnett, R. (1992). The idea of quality: Voicing the educational. Higher Education Quarterly, 46(1), 3-19. https://doi.org/10.1111/j.1468-2273.1992.tb01581.x

Batchelor, D. (2006). Becoming what you want to be. London Review of Education, 4(3), 225-238. https://doi.org/10.1080/14748460601043841

Benoot, C., Hannes, K., \& Bilsen, J. (2016). The use of purposeful sampling in a qualitative evidence synthesis: A worked example on sexual adjustment to a cancer trajectory. BMC medical research methodology, 16(1), 21. https://doi.org/10.1186/s12874-016-0114-6

Billington, R. (2002). Living philosophy: An introduction to moral thought (3rd ed.). London: Routledge. https://doi.org/10.4324/9780203009819

Bok, D. (2006). Our underachieving colleges. Princeton, NJ: Princeton University.

Briggs, S. (2006). An exploratory study of the factors influencing undergraduate student choice: The case of higher education in Scotland. Studies in Higher Education, 31(6), 705-722. https://doi.org/10.1080/03075070601004333

Cavana, R. Y., Delahaye, B. L., \& Sekaran, U. (2001). Applied business research: Qualitative and quantitative methods. Milton, Qld: John Wiley \& Sons Inc.

Crisp, G., Palmer, E., Turnbull, D., Netelbeck, T. Ward, L., \& Schneider, L. (2009). First year student expectations: Results from a university-wide student survey. Journal of University Teaching \& Learning Practice, 6(1). Retrieved from http://ro.uow.edu.au/jutlp/vol6/iss1/3

Demirtas, H., \& Coban, D. (2014). Metaphors that university students generate about the university and faculty concepts (Case Study at the University of Inonu). Ondokuz Mayis University, Journal of Education, 33(1), 113-143. https://doi.org/10.7822/egt203

Dewey, J. (1996). Democracy and education: An introduction to the philosophy of education. New York, NY: The Free.

Ertem, Z. S., \& Ari, A. (2016). High school students' perception of university and faculty members. Cumhuriyet International Journal of Education, 5(3), 78-92. e-ISSN: 2147-1606. https://doi.org/10.30703/cije.321408

Grifth, L. (2017). International Trends in Higher Education 2016-17. Retrieved from http://www.ox.ac.uk/sites/files/oxford/trends\%20in\%20globalisation_WEB.pdf

Immerwahr, J. (2002). The affordability of higher education: A review of recent survey research. The National Center for Public Policy and Higher Education.

Kalayci, N., \& Ilhan, E. (2017). Core curriculum in higher education. Journal of Higher Education and Science, 7(1), 118-131. https://doi.org/10.5961/jhes.2017.190

Kalayci, N., Watty, K., \& Hayirsever, F. (2008, Oct). Academics'perceptions and expectations on attaining the purposes of higher education: Cases in Turkey and Australia. Paper presented at the Eleventh International Conference on Further Education in the Balkan Countries, Konya, Turkey.

Kandiko, C. B., \& Mawer, M. (2013). Student expectations and perceptions of higher education. London: King's Learning Institute.

Komus, M. (2019, June 30). Bir garip sistem. BirGün. Retrieved from 
https://www.birgun.net/haber-detay/bir-garip-sistem.html

Korkmaz, F., \& Bagceci, B. (2013). An examination of high school students' metaphoric perceptions on the concept of "university". Bartin Üniversity, Journal of Faculty of Education, 2(1), 187-204. https://doi.org/10.14686/201312025

Korukoglu, A. (2003). University students' expectations from education: Case of Ege University, Faculty of Economics and Administrative Sciences. Süleyman Demirel University, The Journal of Faculty of Economics and Administrative Sciences, 8(1), 79-89.

Kumar, R. (1996). Research methodology. Malaysia: Sage.

Lai, K. W. (2011). Digital technology and the culture of teaching and learning in higher education. Australasian Journal of Educational Technology, 27(8), 1263-1275. https://doi.org/10.14742/ajet.892

Longden, B. (2006). An institutional response to changing student expectations and their impact on retention rates. Journal of Higher Education Policy and Management, 28(2), 173-187. https://doi.org/10.1080/13600800600751044

Miles, M. B., \& Huberman, A. M. (1994). Qualitative data analysis: An expanded sourcebook. Thousand Oaks, CA: Sage.

Ministry of Education (2019). National education statistics 2017-2018. Retrieved from http://sgb.meb.gov.tr/www/icerik_goruntule.php?KNO=327

Patton, M. Q. (2002). Qualitative research and evaluation methods. Thousand Oakes, CA: Sage.

Randall, B., \& Good, J. W. (2004). Educare and educere is a balance possible in the educational system? Educational Forum, 68(2), 161-168. https://doi.org/10.1080/00131720408984623

Robertson, S. L. (2010). Challenges facing universities in a globalising world. Published by the Centre for Globalisation, Education and Societies, University of Bristol, Bristol, UK. Retrieved from:

https://susanleerobertson.files.wordpress.com/2012/07/2010-robertson- challenges.pdf

Sahin, I., Zoraloglu, Y. R., \& Sahin-Firat, N. (2011). University students' aims in life, educational goals, expectations from the university and their state of satisfaction. Educational Administration: Theory and Practice, 17(3), 429-452.

Sahin, M., \& Yildiz, R. (2005). Future design and university perceptions of the high school adolescence. Dumlupinar University, The Journal of Social Sciences, 14.

Sirin, S. (2017). Dünyada öğrenme motivasyonu en yüksek gençler bizde. Retrieved from http://www.hurriyet.com.tr/yazarlar/selcuk-sirin/dunyada-ogrenme-motivasyonu-en-yuksek-gencler-bizde-404653 60

Strauss, A. L., \& Corbin, J. (1990). Basic of qualitative research: Grounded theory procedures and techniques. Newbury Park, CA: Sage.

Task Force on Higher Education and Society. (2000). Higher education in developing countries: Peril and promise. Washington, DC: World Bank. https://doi.org/10.1596/0-8213-4630-X

TEDMEM (2018). Prof. Dr. İoanna Kuçuradi ile felsefe ve eğitim üzerine. Retrieved form https://tedmem.org/dosya-konusu/prof-dr-ioanna-kucuradi-ile-felsefe-egitim-uzerine

The Higher Education Council (2018). 2018 YKS-Yükseköğretime yerleştirme sonuçlarına ilişkin sayısal bilgiler. Retrieved from https://dokuman.osym.gov.tr/pdfdokuman/2018/YKS/YER/SayisalBilgiler31082018.pdf

The Higher Education Council. (2019). Universities. Retrieved from https://www.yok.gov.tr/universiteler/universitelerimiz

Xu, H. (2011). Students' perceptions of university education- USA and China. Research in Higher Education Journal $10(1), 1-10$.

\section{Copyrights}

Copyright for this article is retained by the author(s), with first publication rights granted to the journal.

This is an open-access article distributed under the terms and conditions of the Creative Commons Attribution license which permits unrestricted use, distribution, and reproduction in any medium, provided the original work is properly cited. 